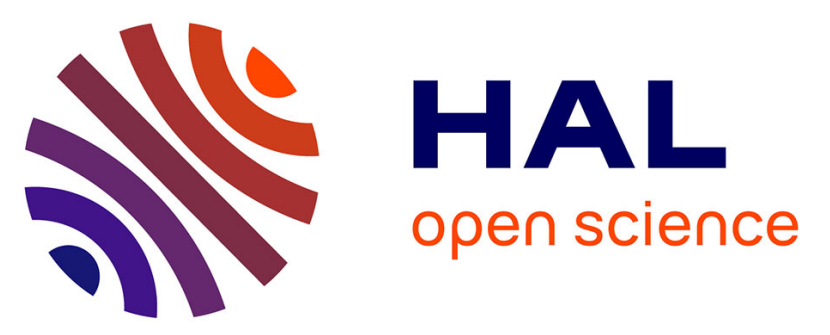

\title{
The Pig's other genome: a reference gene catalogue of the gut microbiome as a new resource for deep studies of the interplay between the host and its microbiome
} Liang Xiao, Jordi Estellé, Pia Kiilerich, Yuliaxis Ramayo-Caldas, Zhongkui Xia, Qiang Feng, Niels Jørgen Kjeldsen, Emmanuelle Maguin, Joel Dore, Nicolas Pons, et al.

\section{To cite this version:}

Liang Xiao, Jordi Estellé, Pia Kiilerich, Yuliaxis Ramayo-Caldas, Zhongkui Xia, et al.. The Pig's other genome: a reference gene catalogue of the gut microbiome as a new resource for deep studies of the interplay between the host and its microbiome. 35. International Society for Animal Genetics Conference (2016), Jul 2016, Salt Lake City, United States. 10.2527/jas2016.94supplement422x . hal-02741979

\author{
HAL Id: hal-02741979 \\ https://hal.inrae.fr/hal-02741979
}

Submitted on 3 Jun 2020

HAL is a multi-disciplinary open access archive for the deposit and dissemination of scientific research documents, whether they are published or not. The documents may come from teaching and research institutions in France or abroad, or from public or private research centers.
L'archive ouverte pluridisciplinaire HAL, est destinée au dépôt et à la diffusion de documents scientifiques de niveau recherche, publiés ou non, émanant des établissements d'enseignement et de recherche français ou étrangers, des laboratoires publics ou privés. 


\section{The Pig's other genome: a reference gene catalogue of the gut microbiome as a new}

resource for deep studies of the interplay between the host and its microbiome

Liang Xiao ${ }^{1}$, Jordi Estellé ${ }^{2}$, Pia Kiilerich ${ }^{3}$, Yuliaxis Ramayo-Caldas ${ }^{2}$, Zhongkui Xia ${ }^{1}$, Qiang Feng $^{1}$, AnniØyan Pedersen ${ }^{4}$, Niels Jørgen Kjeldsen ${ }^{4}$, Emmanuelle Maguin ${ }^{5}$, Joël Doré ${ }^{5,6}$, Nicolas Pons ${ }^{5,6}$, Emmanuelle Le Chatelier ${ }^{5,6}$, Lise Madsen ${ }^{1,3,7}$, Jun Wang ${ }^{1}$, Stanislav D. Ehrlich $^{6,8}$, Karsten Kristiansen ${ }^{1,3}$, Claire Rogel-Gaillard ${ }^{2}$

${ }^{1}$ BGI-Shenzhen, 518083 Shenzhen, China.

${ }^{2}$ GABI, INRA, AgroParisTech, Université Paris-Saclay, 78350 Jouy-en-Josas, France

${ }^{3}$ Department of Biology, University of Copenhagen, DK-2200, Copenhagen, Denmark.

${ }^{4}$ Danish Pig Research Centre, Nutrition and Reproduction, DK-1600 Copenhagen V, Denmark.

${ }^{5}$ MICALIS Institute, INRA, AgroParisTech, Université Paris-Saclay, 78350 Jouy-en-Josas, France.

${ }^{6}$ MGP MetaGénoPolis, INRA, Université Paris-Saclay, 78350 Jouy-en-Josas, France.

${ }^{7}$ National Institute of Nutrition and Seafood Research (NIFES), Postboks 2029, Nordnes, N5817 Bergen, Norway

${ }^{8}$ King's College London, Centre for Host-Microbiome Interactions, Dental Institute Central Office, Guy’s Hospital, United Kingdom.

\section{Up to 400 words (360 words)}

The pig is a major species for livestock production and is also extensively used for biomedical research. A reference catalogue of gut microbial genes would clearly complement the recently established pig genome sequence. We established a comprehensive catalogue of gut microbial genes from 287 pigs from France, Denmark and China. Deep sequencing of fecal DNA samples generated 1,758 Gigabases $(\mathrm{Gb})$ of high quality data with an average of $6.125 \mathrm{~Gb}$ per sample. The dataset allowed us to identify 7,685,872 non-redundant (NR) genes with an average contigN50 length of 1.89 Kilobases, together with 719 metagenomic species (MGS). $50 \%$ of the NR genes could be taxonomically classified, and of these more than $98 \%$ could be assigned to the Bacteria super kingdom. At the phylum level, Firmicutes was the most abundant followed by Bacteroidetes. At the genus level, Prevotella was the most abundant followed by Bacteroides, Clostridium, Ruminococcus and Eubacterium. We identified a common set of 4,430 NR genes, 36 MGS and 3,463 related annotated functions shared by 
$100 \%$ of the 287 pig samples, suggesting the existence of a core of genes, species, and functions in the gut microbiome in pigs. The pig and human catalogues share $12.6 \%$ and 9.3 $\%$ of their genes, respectively, a higher proportion than that shared between the mouse and human catalogues. Importantly, $78 \%$ and $96 \%$ of the functional pathways are shared, underscoring the potential use of pigs for biomedical research. The pig metagenome exhibited a higher alpha diversity than both the human and mouse microbiomes, and lower beta diversity than the human metagenome at the gene, genus, and KEGG levels. We show that gender, age and host genetics markedly influence the pig gut microbiome. We report a common set of antibiotic resistance genes (ARGs) found in all pigs, regardless the country of origin or the supplementation with antibiotics, but show a significantly greater ARG load in animals continuously fed antibiotics. Thus, our data confirmed the efficiency of eliminating antibiotics from animal diet to reduce the risk of dissemination associated with farming systems. The pig microbiome gene catalogue reported here provides a straightforward new resource for metagenomics-based research in biomedicine and for sustainable knowledgebased pig farming. 